\title{
Inheritance of Tolerance to Mineral Element-induced Chlorosis in Rabbiteye Blueberry
}

Creighton L. Gupton and James M. Spiers

U.S. Department of Agriculture-Agricultural Research Service, Small Fruit Research Station, Poplarville, MS 39470

Additional index words. Vaccinium ashei, blueberry breeding, heritability, genetic correlations, diallel analysis, mineral nutrition

Abstract. A study of leaf chlorosis in rabbiteye blueberries (Vaccinium ashei Reade) grown in soil containing 300 to $400 \mathrm{ppm}$ diethylenetriaminepentaacetic acid (DTPA)extracted Mn revealed no relationship between leaf Mn content and chlorosis. A second study was conducted to estimate heritability of the content of $\mathrm{Mn}, \mathrm{Fe}$, and certain other mineral elements that have been associated with leaf chlorosis and to determine the genetic relationships among shoot dry weight, visual rating, and the mineral elements in rabbiteye blueberry. Heritability estimates were high for all variables except Fe, suggesting that changes in $\mathrm{Mn}, \mathrm{Zn}, \mathrm{Ca}, \mathrm{Mg}$, or $\mathrm{K}$ contents could be expected from phenotypic recurrent selection. However, manipulation of mineral content probably would not ameliorate the Fe chlorosis. The high heritability of shoot dry weight and visual rating and the high genetic correlation between these variables suggest that plants resistant to mineral effects on Fe metabolism can be selected on the basis of visual rating.

Iron chlorosis of blueberry has been observed on mineral soils since the 1930s (Bai-

Received for publication 3 May 1991. Accepted for publication 6 Aug. 1991. The cost of publishing this paper was defrayed in part by the payment of page charges. Under postal regulations, this paper therefore must be hereby marked advertisement solely to indicate this fact. ley, 1936), and it remains a major problem today (Korcak, 1989). Iron concentrations in chlorotic leaves are often equal to or higher than those found in green leaves (Cain, 1952; Korcak, 1989). Factors, such as form of $\mathrm{N}$ (Cain, 1954; Spiers, 1979), P content (Holmes, 1960; Korcak, 1989), K content (Cain, 1954), Ca content (Bailey, 1941), high micronutrient levels (Korcak, 1989), and tis- 


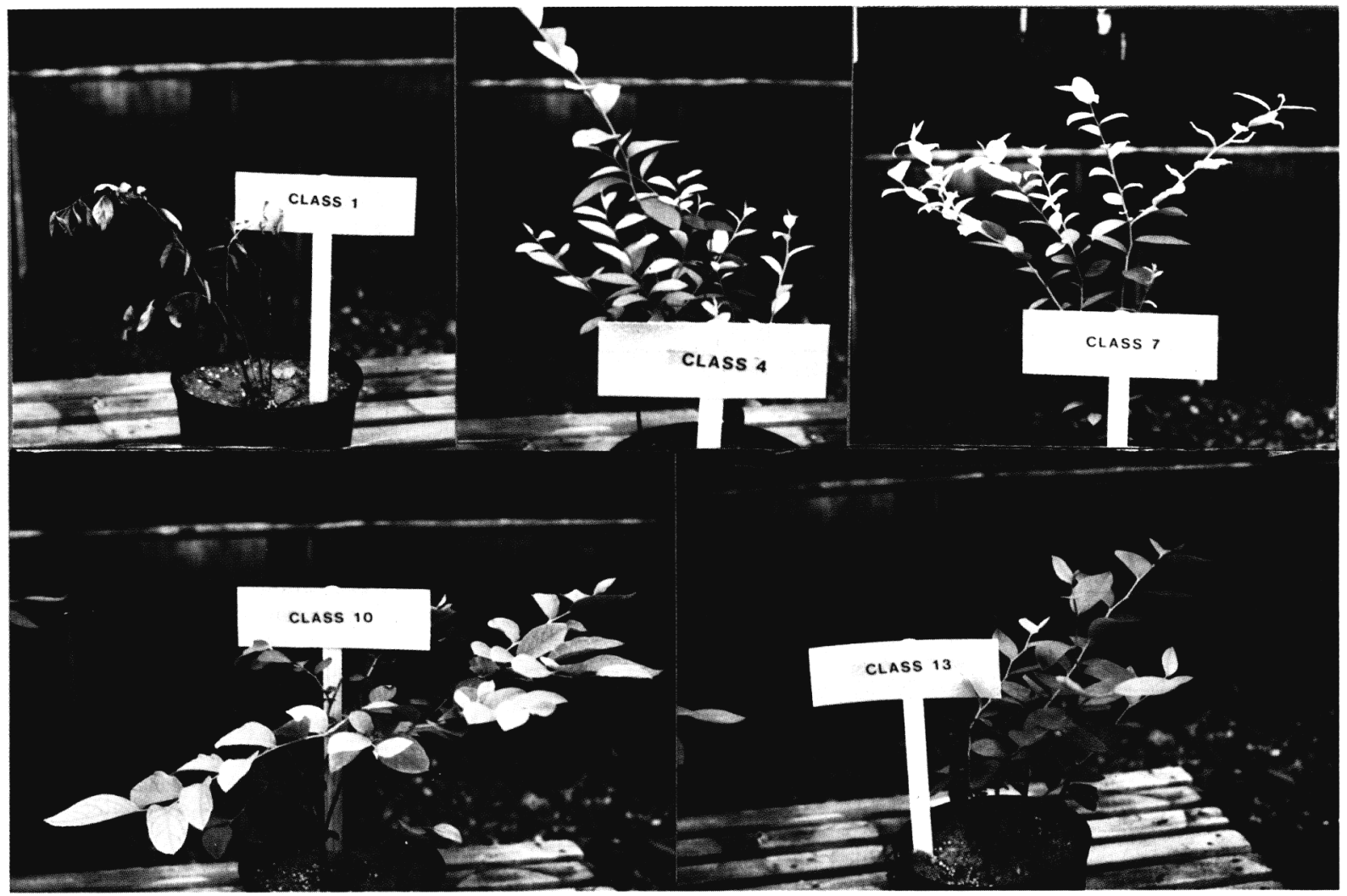

Fig. 1. Typical blueberry plant for five of the 13 classes into which 10 plants from each cross derived from a lo-parent diallel set of crosses and fertilized with a 250-ppm Mn solution were classified after 6 weeks of growth.

Table 1. Characteristics of certain rabbiteye blueberry clones grown in soil containing 300 to 400 ppm diethylenetriaminepentaacetic acid-extracted $\mathrm{Mn}$.

\begin{tabular}{lcccc}
\hline \hline & \multicolumn{2}{c}{ Mn content } & \\
\cline { 3 - 4 } Clone & $\begin{array}{c}\text { Visual } \\
\text { rating }\end{array}$ & $\begin{array}{c}\text { Leaf mean } \\
(\mathrm{ppm})\end{array}$ & $\begin{array}{c}\text { Ratio } \\
\text { basal }: \text { tip leaves }\end{array}$ & $\begin{array}{c}\text { Soil } \\
\mathrm{pH}^{\mathbf{y}}\end{array}$ \\
\hline T102 $^{\mathrm{x}}$ & $4.5 \mathrm{a}$ & $245 \mathrm{ab}$ & $1.3: 1$ & $4.4 \mathrm{ab}$ \\
T172 & $4.5 \mathrm{a}$ & $394 \mathrm{a}$ & $4.5: 1$ & $4.4 \mathrm{ab}$ \\
Climax & $1.5 \mathrm{~b}$ & $303 \mathrm{ab}$ & $4.4: 1$ & $4.4 \mathrm{ab}$ \\
Tifblue & $2.5 \mathrm{~b}$ & $200 \mathrm{~b}$ & $4.8: 1$ & $4.5 \mathrm{a}$ \\
T129x & $1.0 \mathrm{c}$ & $311 \mathrm{ab}$ & $4.8: 1$ & $4.3 \mathrm{~b}$ \\
\hline
\end{tabular}

${ }^{{ }^{2}}$ Subjective rating, 1 = least plant vigor, most leaf chlorosis or necrosis; $5=$ most plant vigor, least chlorosis.

'Means within a column are separated by Wailer-Duncan K-ratio $t$ test.

'Selection from the Georgia Agricultural Experiment Station-U.S. Dept. of Agriculture breeding program.

sue $\mathrm{pH}$ (Cain, 1954), have been associated with $\mathrm{Fe}$ chlorosis in blueberry. In a review of other crops, Foy et al. (1978) stated, "chlorosis from excess $\mathrm{Zn}, \mathrm{Cu}, \mathrm{Ni}$, and $\mathrm{Cd}$ appears to be due to direct or an indirect interaction with foliar Fe." White et al. (1974) hypothesized that $\mathrm{Zn}$ and $\mathrm{Mn}$ interfere with Fe use for chlorophyll synthesis in the leaves. Many enzyme systems of plants that are activated by $\mathrm{Mg}$ also respond to $\mathrm{Mn}$ (Woolhouse, 1983). Blueberries accumulate large amounts of Mn, which has been associated with Fe chlorosis in other crops (Foy et al., 1978). Foy et al. (1978) concluded that metal toxicities in plants are often not clearly identifiable but may result from complex interaction of the major toxic ions in question with other essential or nonessential ions and with environmental factors.
Investigation of chlorosis in research plots at Poplarville, Miss., revealed a rather high (300 to 400 ppm) soil Mn content (D. Creech, personal communication). The objective of our field experiment was to determine the relationship of soil $\mathrm{pH}$ and leaf $\mathrm{Mn}$ content to observed variability in leaf chlorosis and plant vigor. A study with pots in a shadehouse was designed to estimate heritability $\left(\mathrm{h}^{2}\right)$ of the content of $\mathrm{Mn}, \mathrm{Fe}$, and some other mineral elements that have been associated with leaf chlorosis and to determine the genetic relationships among shoot dry weight, visual rating, and mineral element content.

Four single-plant replicates of three selections and two cultivars (Table 1) were evaluated for plant vigor, leaf chlorosis and $\mathrm{Mn}$ content, and $\mathrm{pH}$ of soil near the roots. A visual rating was recorded for each plant where $1=$ least plant vigor and most leaf chlorosis and $5=$ most plant vigor and least chlorosis. Terminal leaf samples consisted of the last three fully expanded leaves, and basal leaf samples consisted of the three basal-most leaves collected from several shoots on each plant. The leaves were dry-ashed using the *procedures of Jones and Case (1990) with the following modifications: 1) One gram of tissue was weighed and ashed at $450 \mathrm{C} ; 2$ ) the ash was dissolved in $5 \mathrm{ml}$ of $20 \% \mathrm{HCl}$ on a hot plate; and 3) the solution was transferred to a volumetric flask and brought to $100 \mathrm{ml}$ with deionized water. Manganese content was determined on an Instrumentation Laboratory (Wilmington, Mass.) $157 \mathrm{AA} /$ $\mathrm{AE}$ Spectrophotometer. Soil cores were taken to a $15-\mathrm{cm}$ depth underneath the canopy of each plant and the $\mathrm{pH}$ of a 1 soil $: 2$ distilled water (w/v) soil solution was determined on an Orion (Boston) SA $520 \mathrm{pH}$ meter.

Ten plants from each progeny of a loparent diallel set of crosses, excluding selfs and reciprocals, were arranged in a randomized complete-block design with five twoplant replicates. Parents included the five clones evaluated in the field (Table 1) plus 'Aliceblue', 'Beckyblue', 'Brightwell', 'Briteblue', and 'Premier'. The roots of 1year-old seedlings were washed before being planted in 2-liter pots containing washed sand in a shadehouse. A 250-ppm Mn solution derived from $\mathrm{MnSO}_{4} \cdot \mathrm{H}_{2} \mathrm{O}$ and adjusted to a $\mathrm{pH}$ of 4.5 was applied 5 daysweek $^{-1}$ at 200 $\mathrm{ml} /$ pot followed by leaching the next 2 days 
Table 2. Range of progeny values (mean of 10 plants) and heritability estimates from analyses of a lo-parent diallel set of crosses of blueberries.

\begin{tabular}{lccc}
\hline \hline Variable & Range of value & Heritability $\left(\mathbf{h}^{2}\right)$ & SE \\
\hline Shoot wt (g) & $1.0-9.1$ & 0.37 & 0.21 \\
Visual rating & $4.3-9.6$ & 0.43 & 0.24 \\
Mn content (ppm) & $888-1941$ & 0.60 & 0.35 \\
Zn content (ppm) & $22-52$ & 0.48 & 0.30 \\
Ca content (\%) & $0.14-0.28$ & 0.67 & 0.34 \\
Mg content (\%) & $0.06-0.10$ & 0.59 & 0.36 \\
Fe content (ppm) & $28-63$ & 0.13 & 0.16 \\
$\mathrm{~K}$ content (\%) & $1.1-3.4$ & 0.58 & 0.32 \\
Ca + Mg + K $(\%)$ & $1.4-3.7$ & 0.56 & 0.31 \\
\hline
\end{tabular}

${ }^{2}$ Subjective rating, $1=$ dead plant; $13=$ most plant vigor, least chlorosis.

Table 3. Genetic correlations among shoot dry weight, visual rating, and mineral content of plants from a lo-parent diallel set of crosses.

\begin{tabular}{|c|c|c|c|c|c|c|c|}
\hline \multirow[b]{2}{*}{ Variable } & \multirow{2}{*}{$\begin{array}{l}\text { Visual } \\
\text { rating }\end{array}$} & \multicolumn{6}{|c|}{ Mineral element content } \\
\hline & & $\mathrm{Zn}$ & $\mathrm{Ca}$ & $\mathrm{Mg}$ & $\mathrm{Mn}$ & $\mathrm{K}$ & $\mathrm{Ca}+\mathrm{Mg}+\mathbf{K}$ \\
\hline Shoot wt & 0.99 & -0.60 & 0.11 & -0.78 & -0.07 & -0.51 & -0.49 \\
\hline Visual rating & & -0.42 & 0.11 & -0.78 & -0.28 & -0.38 & -0.38 \\
\hline $\mathrm{Zn}$ content & & & 0.87 & 0.88 & 0.65 & 0.63 & 0.74 \\
\hline Ca content & & & & 0.61 & 0.98 & 0.23 & 0.37 \\
\hline $\mathrm{Mg}$ content & & & & & 0.97 & 0.20 & 0.29 \\
\hline Mn content & & & & & & 0.56 & 0.69 \\
\hline K content & & & & & & & 0.99 \\
\hline
\end{tabular}

with tap water. A solution of (15N-9P-12K) Peters soluble fertilizer with trace elements (W.R. Grace, Foglesville, Pa.) at $200 \mathrm{ml} /$ pot was applied at the beginning and weekly following leaching during the first 5 weeks. Because plants began to require water in addition to the fertilizer solutions at this time, Osmocote (14N-6P-12K) (Sierra Chemical, Milpitas, Calif.) was applied to ensure adequate macronutrients, and the pots were uniformly irrigated with tapwater as needed.

After 6 weeks each plant was classified on a scale of $1=$ dead plant to $13=$ vigorous plant with no chlorosis (Fig. 1). Ten weeks after the experiment was initiated, all new shoots grown during that time were collected and dried in an oven at 70C. Total shoot weight from each plant was recorded. The leaves were then stripped, and $\mathrm{Mn}, \mathrm{Zn}$, and $\mathrm{Fe}$ concentrations were determined by the method described for $\mathrm{Mn}$ in the field experiment. The solution resulting from the dryashing procedure described above was diluted 1: $10(\mathrm{v} / \mathrm{v})$ with a $0.5 \% \mathrm{La}_{2} \mathrm{O}_{3}$ solution to determine $\mathrm{Ca}, \mathrm{Mg}$, and $\mathrm{K}$ on the spectrophotometer. Visual rating, shoot weight, and $\mathrm{Mn}, \mathrm{Fe}, \mathrm{Zn}, \mathrm{Ca}, \mathrm{Mg}$, and $\mathrm{K}$ content were analyzed by the general least squares diallel analysis of Schaffer and Usanis (1969). Estimates of narrow sense heritability $\left(\mathrm{h}^{2}\right)$ for each variable and genetic correlations among all variables were computed.

Visual ratings of five clones in the field revealed three significantly different levels of leaf chlorosis and plant growth (Table 1). Average Mn content of the leaves was high and variable among clones, but none were above the published toxicity level of $450 \mathrm{ppm}$ (Eck, 1988). The Pearson correlation coefficient between visual rating and Mn content was only 0.06 , suggesting that Mn content per se does not account for the variation in plant vigor and chlorosis. T172, one of the most vigorous and least chlorotic clones, had the highest Mn content. This phenomenon has been observed in other species (Smith, 1979). The ratio of Mn content in the basal to that in the tip leaves was lowest in T102 and similar in the other clones. Tolerance to excess Mn probably was not related to its entrapment in nonmetabolic centers in older leaves (Foy et al., 1978), since there was no consistent relationship between visual ratings and ratio of Mn content in basal to that in terminal leaves. Any effect of Mn on chlorosis and plant growth was probably caused by its interaction with $\mathrm{Fe}$ or other mineral elements. The $\mathrm{pH}$ of soil near roots varied only slightly among clones, although that for T129, which had the lowest visual rating, was significantly lower than that for 'Tifblue', which had a significantly higher visual rating and the lowest $\mathrm{Mn}$ content (Table 1). 'Tifblue' has been found to accumulate less Mn than other clones in a previous study (Korcak, 1988).

The Mn content of all plants in pots was higher than the reported toxicity level (Table $2)$. Potassium content exceeded the maximum sufficiency range $(0.60 \%)$ in all plants. Zinc content was near or above the maximum sufficiency value (30 ppm), Ca and Fe content were near the minimum sufficiency value $(0.20 \%$ and $60 \mathrm{ppm}$, respectively), and $\mathrm{Mg}$ content was near or below the deficiency level $(0.08 \%)$. Sufficiency range for each of the above mineral elements appears in Eck (1988).

An almost perfect genetic correlation between shoot dry weight and visual rating suggests that subjective evaluation characterizes plant growth equally as well as shoot dry weight (Table 3). A negative correlation existed between $\mathrm{Zn}, \mathrm{Mg}$, and $\mathrm{K}$ content and shoot weight or visual rating, but no genetic relationship was found between either $\mathrm{Ca}$ or $\mathrm{Mn}$ and these traits. The negative value for $\mathrm{Mg}$ is puzzling because $\mathrm{Mg}$ content was near the deficiency level. Perhaps $\mathrm{Mg}$ had an additive effect with the excess Mn since Woolhouse (1983) has observed that many enzyme systems of plants that are activated by $\mathrm{Mg}$ also respond to $\mathrm{Mn}$. A high correlation existed among $\mathrm{Zn}, \mathrm{Ca}, \mathrm{Mg}$, and $\mathrm{Mn}$ content. Potassium content was positively correlated with $\mathrm{Zn}, \mathrm{Ca}, \mathrm{Mg}$, and $\mathrm{Mn}$ content. A negative relationship was found between total basic cations $(\mathrm{Ca}+\mathrm{Mg}+\mathrm{K})$ and visual rating or shoot dry weight. This result supports the postulate by Cain (1954) that these cations might be a regulating factor in the function of $\mathrm{Fe}$ through their effect on the plant buffer system and might also explain the negative effect of $\mathrm{Mg}$. Potassium comprised most of the basic cation content, however, and its high content could have had an effect independently of that on the buffer system. The correlation between $\mathrm{K}$ and total basic cations was 0.99 .

Heritability estimates were high for all variables, except Fe (Table 2). Little or no genetic variability existed for Fe content, which could have been affected by excess $\mathrm{Mn}$ and $\mathrm{K}$, total cation content, or interactions with metals. Under the conditions of this experiment, it would be difficult to select for increased $\mathrm{Fe}$ content. Considerable change in $\mathrm{Mn}, \mathrm{Zn}, \mathrm{Ca}, \mathrm{Mg}$, or $\mathrm{K}$ content could be expected from phenotypic recurrent selection. However, manipulation of mineral content probably would not ameliorate the Fe chlorosis. The high heritability of shoot dry weight and visual rating suggests that plants resistant to the effects of other minerals on Fe metabolism can be selected on the basis of visual rating. In making selections, mineral content can be disregarded, thereby saving the cost of plant analyses and simplifying breeding methodology to develop plant populations resistant to Fe chlorosis. For practical purposes, it is unnecessary to identify the causes of $\mathrm{Fe}$ chlorosis or the nature of resistance because plants with resistant enzyme systems or other resistance mechanisms can be identified subjectively. Although the causes of Fe chlorosis in blueberry are evidently many and complex, resistant genotypes can be selected from the germplasm we studied.

\section{Literature Cited}

Bailey, J.S. 1936. A chlorosis of cultivated blueberries. Proc. Amer. Soc. Hort. Sci. 34:395396.

Bailey, J.S. 1941. The effect of lime applications on the growth of cultivated blueberry plants. Proc. Amer. Soc. Hort. Sci. 38:465-467.

Cain, J.C. 1952. A comparison of ammonium and nitrate nitrogen for blueberries. Proc. Amer. Soc. Hort. Sci. 59:161-166.

Cain, J.C. 1954. Blueberry chlorosis in relation to leaf $\mathrm{pH}$ and mineral composition. Proc. Amer. Soc. Hort. Sci. 64:61-70.

Eck, P. 1988. Blueberry science. Rutgers Univ. Press, New Brunswick, N.J., and London.

Foy, C.D., R.L. Chang, and M.C. White. 1978. The physiology of metal toxicity in plants. Annu. Rev. Plant Physiol. 29:511-566.

Holmes, R.S. 1960. Effect of phosphorus and $\mathrm{pH}$ on iron chlorosis of the blueberry in water culture. Soil Sci. 90:374-379. 
Jones, J.B., Jr., and V. W. Case. 1990. Sampling, handling, and analyzing plant tissue samples, p. 389-427. In: R.L. Westerman (ed.). Soil testing and plant analysis. SSSA Book series 3 . Soil Sci. Soc. Amer., Madison, Wis.

Korcak, R.F. 1988. Response of blueberry species to excessive manganese. J. Amer. Soc. Hort. Sci. 113:189-193.

Korcak, R.F. 1989. Influence of micronutrient and phosphorus levels and chelator to iron ratio on growth, chlorosis, and nutrient of Bluecrop highbush blueberries. J. Plant Nutr. 12:1293 1310.

Shaffer, H.E. and R.A. Usanis. 1969. General least squares analysis of diallel experiment: A computer program diallel. North Carolina State Univ. Genet. Dept., Rpt. 1.

Spiers, J.M. 1979. Influence of oxidized and reduced $\mathrm{N}$ on Tifblue rabbiteye blueberry growth, p.. 64-67. In: J.N. Moore (ed.1. Proc. 4th North Amer. Blueberry Res. Workers Conf., Univ. of Arkansas, Fayetteville.

Smith, F.W. 1979. Tolerance of seven tropical pasture grasses to excess manganese. Commun. Soil Sci. Plant Anal. 10:853-867.

White, M.C., R.L. Chaney, and A.M. Decker 1974. Differential varietal tolerance in soybean to toxic levels of zinc in Sassafras sandy loam. Agron. Abstr. 1974:144-145.

Woolhouse, H.W. 1983. Toxicity and tolerance in the response of plants to metals. p. 254-300. In: O.L..Lange, P.S. Nobel, C.B. Osmond, and H. Ziegler (eds.). Physiological plant and ecology III. Responses to the chemical and biological environment. Springer-Verlag, Berlin. 